\title{
Economic Perspective, Cultural Perspectives, and Sharia Perspective in Revenue Sharing For Village Economic Empowerment (Case Study on Gaduh Culture in East Java)
}

\author{
Moch. Khoirul Anwar ${ }^{1 *}$ and Hariyati \\ ${ }^{1,2}$ Surabaya State University, Surabaya, Indonesia
}

\begin{abstract}
Theoretically, revenue is one of local wisdom community empowerment models which is effective nowadays. This model is based on potential and social fabric conditions of the local community. The study aims to analyze the influence of the economic perspectives, cultural perspective and sharia perspective on revenue of society's income in East Java.

This study uses a mixed methods study, with a qualitative and quantitative approach. The population and samples are the society in Blitar, Jombang, and Madiun. The result of the qualitative analysis showed that there are three (3) models of implementasion in cow-calf lease agreement (gaduh) and share farming (paron) system. The first model implements profit sharing system by taking maintenance cost into account. The second model implements sharing system as well but it takes farming workers in the deficit of profit cost into account. The revenue that is based on profit sharing is still in 50:50. While the third model uses revenue sharing system without taking administration and workers cost as the cost component. However, the revenue proportion becomes 75:25. Those models are reviewed from shariah perspective, economic perspective and cultural perspective. From quantitative analysis showed that economic perspective has bigger influence.
\end{abstract}

Keywords: Economic Perspectives, Mixed Method, Profit Sharing, Revenue, Shariah Perspective

\section{INTRODUCTION}

Gaduhan (Cow-calf lease agreement) is the term for revenue in the farm field which is usually practiced on society's farms. While Parohan ( share farming ) is the term of revenue for farmers. Gaduhan and Parohan is one of economic systems which is commonly used in rural areas in Indonesia that has existed since the ancient time. This system is based on mutual cooperation culture and trust that has been accustomed to do in the countryside .

The revenue practice of the agricultural land and maintenance of cattle in Indonesia has lasted a long time with tradisional system. There is no certain system that regulates it formally and writes about it, because a culture of trust, mutual help and mutual cooperation is underlying the system. There are no problems during the implementation of the system

\footnotetext{
* Corresponding author. Email address: emkhoirul@yahoo.com
} 
starting from the beginning to the end of the process. If gaduhan or parohan gives satisfactory results, the results are divided according to the agreement and practice, but if there is a loss, the loss is also borne jointly and the capital owners usually give compensation to rice farmers who do this, although not many.

Related to the knowledge about the rules for revenue and sharia business, theoretically their knowledge is very low, but in practice they are already implementing a system for the results and the business for a long time. The rules about the revenue are based on an agreement between two parties and there is no certain workshop about the revenue so far. There are only workhop about health, farming of cattle and farming.

In this system, cattle and farm are entrusted to someone to develop. Cows deposited ranges from 2 to 5. The ownership of a cow or rice is arising from the purchased by the owner of the fields or cows and subsequently deposited. Rice fields or cows that have been purchased are usually shared with other parties trusted by the owner. In the transaction, no written agreements related to the system because mutual trust is a culture that is becoming a habit in this case. The activity is chosen because hersnments or farmers generally have much spare time. Hence they usually take advantage of free time from the system.

The implementation of the system of revenue sharing among farmers in rural areas, is not only constituted to meet the needs of any material profit but also as a form of communication and kinship adhesive them. In addition, cultural factors and mutual cooperation dominates in this system. The implementation of the system has been very strong in rural community and is proved to spur economic growth. Therefore, this system is to be developed in such a way that it becomes an ethical business and economic activities to empower communities based on the aspect of good cooperation.

This research was specifically conducted to explore the system of revenue from the perspective of economics, culture and sharia in order to increase people's income.

\section{Research Question}

Based on the background above, the questions of this study are as follows :

1. How does the cultural scene in the revenue can increase incomes viewed from the perspective of economics, culture and sharia .

2. How does the economic perspective, culture and sharia affect the increase in people's income.

\section{THEORETICAL FRAMEWORK}

\section{Economic Perspective in Revenue Sharing}

One understanding of economics is the study of how human behave to organize consumption and production activities. Therefore, any economic system including the Islamic system which is applied in this world will always be associated with three main economic problems (The Three Fundamental and interdependent Economic Problem ). These three problems are what items and how much, and to whom they are created and distributed.

Conventional economic system assumes that the optimal welfare will be achieved if each factor of production has been allocated in such a way in order to reach the ideal balance in all sectors of production. In the view of the consumer, 
optimal well-being can be achieved if the distribution of such goods have been allocated to each customer, in order to reach the ideal balance.

Islamic economic concept which is for the public welfare by the treasures of Islamic literature is the ownership of property, including individual ownership, common ownership, and state ownership. The managerial should include the utilization and development of the property. Islamic political economy which is implemented by the state is to ensure the achievement of all basic needs (primary) each individual community globally, warranty which allows each individual to meet the needs of complementary (secondary and tertiary) in accordance with their capabilities.

\section{Syariah Perspective in Revenue Sharing}

Sharing agreement in Shari'ah economy is part of a partnership contract or Syirkah. Etymologically, the word shirkah (company) means mixing (ikhtilat), mixing two or more parts so that it can no longer distinguish between the one with the other part (Syafe 'i, 2001: 183). While according to the terms, syirkah is a partnership contract made by two or more parties to the agreement in terms of capital, skills, or confidence in doing business with the goal of obtaining a profit divided by revenue sharing agreements (Mardani, 2012: 220).

The general form of business for sharing is Musharaka (syirkah or syarikah or union or partnership). The musharaka transaction is based on the desire of the parties working together to increase the value of the assets that they own collectively in groups. Musharaka involves all forms of business that include two or more parties in which they jointly integrate all forms of resources both tangible and intangible. Specifically the contribution of those who cooperate may include funds, goods trade (trading assets), entrepreneurship (entrepreneurship), intelligence (skills), ownership (property), equipment (equipment) or intangible assets (such as patents or goodwill), trust / reputation (credit worthiness) and other items that can be valued in money.

Syirkah law itself is permissible (may). The reason is that many people had been practicing syirkah when the Prophet was sent, and he let such transactions continue to run. In other words, recognition (Taqrir) the Messenger of Allah against those actions constitute arguments of Personality on its mubah. Prophet has allowed Muslims to do trade by syirkah. This is in accordance with the hadith Qudsi which was narrated by Abu Hurairah that the Messenger of Allah said, Verily Allah Almighty has said, "I am the third party of the two parties which do syirkah during one of the two do not betray other colleagues. If one traitor, then I am out of both. "(HR. Al-Bayhaqi and ad- Daruquthni).

Shirkah is part of muamalah (human relations) which may be performed among Muslims or between Muslims with non-Muslim. A Muslim may do syirkah with Nashrani, Jewish or other non-Muslims. Imam Muslim ever narrated from 'Abdullah ibn' Umar as follows: From 'Abd Allah ibn' Umar, from the Prophet that the Prophet had handed palm groves to the Jews of Khaibar to be worked with the capital of their possessions. And he gets half of his harvest. "(HR. Muslim).

In practice, syirkah must meet in pillars and conditions. Mardani (2012: 220) explains that the majority of scholars argue that there are four pillars of syirkah, namely shighat (contract), 'aqidatain (two people who do contract), and ma'qud' alaihi ( object transacted). Shighat is a phrase that came out of each of the two parties to a transaction and shows the will to do the contract. Shighat consists of ijab qabul which can be words and deeds. While aqidatain are two or more parties 
that do contract. Terms of people who do contract is the one that must have skill or eligibility (Ahliyah al-aqad, namely puberty, intelligent, clever, and not blocked to spend possessions) do tasharruf (wealth management). The ma'qud 'alaihi (object) in the form of principal amount can be either property or employment. The conditions of work or objects that must be managed in syirkah is lawful and permissible in the religion and its management may be represented. In addition, it should not be payable in the form of property or objects that are not known because it can not be run to achieve the goal of syirkah, namely benefit.

While the conditions to be met in the contract of syirkah, the scholars agreed that the conditions are as follows:

1. The two parties to a transaction have the capacity or expertise (Ahliyah) to represent and accept representation.

2. Shirkah capital is known.

3. Syirkah capital exists at the time of the transaction.

4. The amount of profit is determined by the sum of the effect, such as a half, a quarter, and so forth.

Regarding the forms syirkah, basically there are only two kinds of syirkah, namely shirkah al milk (ownership) and shirkah al uqud (contract). Shirkah al milk is caused not by contract, but through inheritance, wills, or other conditions that influence the ownership. As for the syirkah contract created due to an agreement between two or more people to work together in providing capital and they agreed to do for both profit and loss results.

According to Sayyid Sabiq, syirkah is divided into several types, namely syirkah `inan, syirkah 'Abdan, syirkah wujuh, and shirkah mufawadhah. Shirkah 'inan is syirkah between two or more parties, each of which contributes to the work (charity) and capital (the mall). Profit-sharing in this syirkah is adjusted by the amount of capital of each syirkah offender, if each capital is $50 \%$, then each bears the loss of 50\% as well. This Shirkah is permissible based on the arguments of the Sunnah and ijma 'friend.

The second form of syirkah according to Sayyid Sabiq is syirkah Abdan, namely syirkah between two or more parties, each of which contributes only work (charity), without any capital contribution (charity). They do the work. Then operating results are divided among them under the agreement, such as a building contractor, roads, electricity and so forth. In some literatures, this syirkah also called shirkah 'charity. For example: A and B are both fishermen and agreed to sail together to catch fish. They also agreed that when obtaining the fish, it will be sold and the results will be shared with provisions: A gains of $60 \%$ and B obtains $40 \%$. This syirkah does not require similar profession or skill. So, syirkah Abdan may consist of several carpenters and plumbers. However, it is required that the work performed is a lawful occupation and can not be an unlawful employment.

The next syirkah form is syirkah wujuh, namely cooperation between two or more people who do not use capital assets, but the trust and profits are shared among their peers. So this syirkah is based on the position, persona, or expertise (Wujuh) of someone in the community. For example: A and B are trusted figure traders. Then A and B do syirkah wujuh by buying goods from a merchant on credit. A and B agree that each has $50 \%$ of the items purchased. Then both sell goods and profits are divided into two. While the basic price is returned to the seller. The profit of the syirkah wujuh is divided by agreement. 
Furthermore, there is a form of syirkah mufawadhah, namely cooperation between two or more persons to conduct a business with the following requirements:

1. The amount of capital must be given in the same number. If the amount of the capital of a member is more, then syirkah mufawadhoh is considered invalid.

2. It has similar authority to act in connection with the law.

3. It has a similarity in terms of religion.

4. Each member has the right to act on behalf of shirkah.

In addition, there are also forms of syirkah called the mudaraba, the business cooperation agreement between the two parties, in which the first party provides the entire capital (shahibul mal), while others become managers or entrepreneurs (mudharib). Mudaraba business profits are divided according to the agreement in the contract, but if there is a loss, it is borned by the owners of capital loss as long as the loss is not due to the negligence of the manager. If the losses are caused by fraud or negligence of the manager, then the manager should be responsible for the losses. The contract is agreed at the beginning so that if there is a profit, then the division will follow the production sharing contract. Suppose a contract for the result is 60: 40, where managers earn $60 \%$ of the profits while capital owners receives $40 \%$ of profits.

In the implementation, mudaraba is divided into two, namely mudharabah muthlaqah and mudaraba muqayadah.Mudharabah muthalaqah is a form of cooperation between capital owners and managers, whose scope is very broad and is not limited by the specifications of the type of business, time, and businesses area. While the mudaraba muthlaqah is the opposite of mudharabah muthlaqah, the business will be run limitedly by the type of business, time, or place of business.

Relating to agriculture, there are several forms syirkah, namely Musaqah, muzara'ah, and Mukhabarah. According to fiqh scholars, musaqah is cooperation between plantation owners and farmers in which the owner's garden hand over to farmers in order to be maintained and the harvest will be divided into two according to the percentage specified in the contract period. Musaqah concept is the concept of mutually beneficial cooperation between the two sides (symbiotic mutualism). It is due to the fact that infrequently the owners of land do not have the time to take care of their farm, while on the other hand there are farmers who have a lot of free time, but do not have land that can be cultivated. With a system musaqah cooperation, each party will equally have benefit and profit.

While muzara'ah and Mukhabarah are equally co-operation in the execution of agricultural land, but has some differences. Muzara'ah is cooperation in agriculture between the landlord and tenant farmers where the seeds come from farmers' crops. While mukhabarah is cooperation in the field of agriculture between landowners and sharecroppers in which the seeds of plants derived from the land owner. Muzara'ah was often identified with mukhabarah. However, both actually have a slight difference. Muzara'ah and Mukhabarah is a form of processing of agricultural cooperation between landowners and tenants that have been known since the time of the Prophet. In this case the landlord gives the tenants of agricultural land to be planted and maintained by the division of a certain percentage of the crop. In Indonesia, particularly in rural areas, the second model of cultivating the land was equally practiced by farming communities. The syari'ah grounding is contained in the hadith and ijma'. In a hadith narrated by Imam Bukhari and Muslim explained that the Prophet never rent the land to the people of 
Khaibar to the agreement that half of the proceeds is to the owner of the land. This hadith has been narrated by some friends, among them are Ibn 'Umar, Ibn 'Abbas and Jabir bin' Abdillah. This hadith is used as a foundation by scholars who allow the practice of muzara'ah and mukhabarah. According to them, muzara'ah and mukhabarah are good cases and are also done by the Messenger of Allah until he died. Practices such cooperation is also followed by Khulafa'ur Rasyidin until they died and then followed by subsequent generations.

\section{Cultural Perspective in Revenue Sharing}

The cooperation which is carried out jointly is called as mutual help, eventually it is becoming strategies of life which alleviates mutual expenses of each label of work. Such cooperation is a proof of harmony between humans for life community, especially for those who still respect and execute the values of life, which is usually done by rural communities or traditional community. But it is still possible that that urban community requires a spirit of mutual assistance. Mutual assistance as a form of social solidarity is formed because there is a help from the other parties, for a review of private or group interests, so that the society has loyality as one unit.

Integrated life of a community can be seen from the solidarity between them through mutual help without the need for a review in return, such as helping unfortunate or distress people. But this kind of help is becoming an obligation to review especially if it deals with the work which is related to farming or celebration. Similarly, if the work that the results are to review the joint interest, then it requires community service.

Mutual assistance activities are carried out by the community of rural or urban area who always require others. The value of mutual assistance in urban area is very different from mutual assistance in rural areas. It is because urban people have been much influenced by the material and wage system, so that trade-offs will be taken into account in conducting mutual assistance, while in rural areas mutual cooperation has not been much affected by the material and wage system so that the activities needed is as a matter of solidarity between people in a single territory or kinship. In this case Koentjaraningrat (1984: 7) suggested mutual assistance activities in rural areas as follows,

a. In case of death, illness, or accident, in which the families who are suffering from it, they will receive aid in the form of energy and matter from neighbors and others entire village;

b. In terms of jobs around the household, for example, repairing roofs, replacing the wall of the house, cleaning the house of the rat, digging wells, etc., For which homeowners can enlist the help of neighbors by providing food assistance;

c. In terms of parties, for example, at the time of marrying, help not only be requested from the relatives, but also of its neighbors, for preparing and organizing the party;

d. In doing useful work for the public interest in rural communities, such as repairing roads, bridges, irrigation dams, public buildings etc., To which the villagers can be moved to devotedly on the orders of the village head.

Mutual assistance can be regarded as the characteristic of the Indonesian people, especially those who live in rural areas who applies for generations, so as to form a real social behavior then shape the values of social life. The existence of these values lead to mutual cooperation that has always nurtured in community life 
as a cultural heritage that should be preserved. Relation to mutual assistance as cultural values, Bintarto (1980: 24) argues that the value was in the system of the culture of Indonesia that contains four concepts, namely: (1) A man is not alone in this world but surrounded by his community, society and the universe around him. Within the macrocosm system he feels himself only as a small element, which is carried on by the circulation of the vast universe. (2) Thus, humans are essentially dependent in all aspects of life to others. (3) Therefore, it should always strive for as much as possible to maintain good relations with others motivated by the soul equally common sense, and (4) always try to the extent possible in conformity, do the same with each other in the community, driven by the spirit of equal height equally low.

The existence of a value system that makes mutual assistance is always maintained and required in many aspects of life, so that mutual assistance will always be in various forms adapted to the cultural conditions of the community. Mutual assistance as a form of integration, is influenced by a sense of togetherness among members of the community who do voluntarily without any collateral in the form of wages or payment in any other form, so that mutual help is not always necessary to form committees formally but notice of activities and execution time is sufficient to the community, then the work is carried out and will be dismissed by itself . The advantages for mutual assistance is that a job becomes easier and lighter than if it is done individually ; it reinforces and strengthens the relationships between members of the community where they are even with relatives who have lived elsewhere, and ; it unites all members of the community involved in it. Thus , mutual assistance can be done to ease the work on agricultural land, to relief work in the events that related to the party which is held by one of the members of the community, or to work together in making and providing a common need .

\section{RESEARCH METHOD \\ Research Approach}

This study uses a mixed method, which uses a qualitative and quantitative approach. Qualitative approach, is a form of research that seeks to provide a systematic and thorough overview of the subject or object of the study. While quantitative approach which is used in this study is on the level of explanatory. It aims to test the hypothesis of the influence of the economic perspective, the perspective of culture and sharia perspective on the output (output) on a culture of rowdy cattle and rice anvil. Data was collected through questionnaire.

The unit of media analysis of this study was rowdy cow business and rice anvil. The respondents of this research are cattleman and cattle owner in Srengat district, Blitar, East Java. This research is a behavioral research that uses the perceptions of cattleman and cattle owners who are considered to have enough knowledge about the culture of gaduhan holistically.

\section{Qualitative Approaches}

In this qualitative approach, validity and reliability of the data are done through triangulation and using the data collaboration. The data then are analyzed qualitatively based on logical thinking analysis. The steps are: 1. Data reduction (to sort the quality of data), 2. Understanding and testing (synchronization attempts to findings and literature review), 3. Interpretation (findings associated with the theory). 


\section{Quantitative Approach}

After a qualitative approach with a focus on the cultural variables that Affect the outcome in rowdy cattle is done, the researcher then analyzes the data quantitatively to obtain justification of the significance of the influence of the variables. In the quantitative approach, there are two types of variables: three (3) independent variables which include an economic perspective, sharia perspective and the perspective of cultural and social, whereas one (1) dependent variable is the outcome of a cultural of rowdy cattle / anvil fields. This study uses Partial Least Square (PLS) data analysis. PLS is a structural equation modeling (SEM) based components or variant (variance). Analysis of structural equation modeling (SEM) with a 4:00 version PLS WARP program is used to test the hypothesis. The variables in this study were classified as follows:

(A) Outcome of the culture for the revenue of cattle (rowdy cattle) / anvil rice is dependent variables with indicator (1) Increase revenues, (2) the aspect of togetherness in the community, (3) maximize the work, (4) a business that is comfortable and serene.

(B) An economic perspective is independent variables with indicator (1) improve the welfare, (2) reduce unemployment, (3) increase revenues, and (4) make ends meet.

(C) Shariah Perspective is independent variables with indicator (1) worship, (2) there is no fraud, (3) the existence of a collective agreement in the business of rowdy / anvil, (4) a fair profit, (5) there are no losers.

(D) The perspective of cultural and social have indicators (1) the activities carried out for generations, (2) people's habits, (3) strengthen silahturahmih, (4) part of helping each other, (5) the sustainability, (6) the support of the penggaduh / owners of capital, (7) lack of support from the government, (8) the support of the community.

Economic perspective, sharia perspective and the perspective of cultural and social influence the outcome of the culture for results in Srengat and Ponggok district in Blitar. The hypothesis in this study are:

1. Economic perspectives influence the outcome of the culture of revenue / rice anvil directly.

2. Sharia perspective influences the outcome of the culture of revenue or rice anvil directly.

3. Social and cultural perspectives affect the outcome of the culture of revenue / rice anvil directly.

The focus of the quantitative approach in this study is the economic perspective, sharia perspective and the perspective of cultural and social influence the outcome of the culture of revenue in Srengat and Ponggok dictrict in Blitar. This study uses data analysis approach Partial Least Square (PLS). PLS is a structural equation modeling (SEM) based components or variant (variance). Analysis of structural equation modeling (SEM) with a 4:00 version PLS WARP program is used to test the hypothesis. 


\section{ANALYSIS AND DISCUSSION}

\section{RESULTS AND DISCUSSION WITH QUALITATIVE APPROACH}

Results and discussion of this study from a qualitative approach are as follows:

1. The implementation of Gaduh (cow-calf lease agreement) and Paron (share farming) Culture in terms of Economic Perspectives.

In general, all of the key informants do not know about Islamic business even though they actually have implemented the business. It is seen that knowledge about the key informant for the results is very low, but in practice they are already applying for the results. Rules about the results in accordance with an agreement between two parties. The rule was never stated in the formal agreement or formal rules. So that all key informants did not know about this Islamic business even though they actually have implemented the business. Islamic business which is applied by cattle farmers (cow-calf lease agreement) and farmers (share farming) is strongly associated with the outcome. Their share mutual trust and mutual respect of rights and its obligations.

Basically the system of profit sharing is an agreement of cooperation between Shohibul malls and businesses in which venture capital is fully (100\%) comes from Shohibul mall. The entrepreneur as a recipient of venture capital-financed manage shohibul malls and shall provide for appropriate agreement. If there is a loss, then the risk is borned by Shohibul mall since the loss is not due to the negligence of the employer or force majeur. This kind of prinsipal force is widely practiced by sharia financial institutions, both micro and macro.

The model of this revenue is also practiced by the public in developing their work. For instance it is done in Blitar, precisely in srengat district. Some people in the area rely on rowdy cow /rice anvil culture in the search for fortune. The activity of rowdy cow and anvil rice with a profit-sharing system that has lasted for generations in rural communities, particularly in Sub Srengat, turned out to have a positive impact on the economy and well-being, namely the effort for this result, people get a chance to take advantage of the ability and energy to work and earn an income, the evidence is that their average income from cow-calf lease agreement / share farming is 1 million per month.

This revenue sharing system has been long known by the people of our farmers. For example is gaduh system, which has been practiced since many years ago by farmers in Central and East Java . Gaduh system is known as the livestock business cooperation of mutual benefit between capital owners with the herdsman. The owner entrusts his livestock to be maintained by the other party, and the result is divided by two. The type of the cattle is usually in the form of beef cattle, buffalo or goat. In Aceh, West Sumatra, South Sulawesi and possibly in other areas, this system has also been put into practice, although under different names. Livestock owners generally have higher level of social and economic life than the herdsman. Care process begins premises qabul consent, usually unwritten, mainly on how to distribute the proceeds of rowdy. Form agreement was adapted to the conditions of the parties to the agreement.

There are two common types of agreements. First, the revenue is done by dividing by the children produced by the livestock. In this case livestock owners entrust an animal as a baboon (the parent). By herdsman, farm animals had been treated to breed. Usually the first derivative of the rights goes to the owner of the livestock, the next birth is for herdsman rights, and so on alternately. 
Another model is the result of profits, based on the agreed ratio. The owner notifies the price of the cattle livestock, then by herdsman maintains it properly. Several years later, after the developed cattle is sold, they sat down together to calculate the sales results. After deducting the purchase price of cattle, they divide the benefit for over a deal that has been made. Other forms of agreement is usually just a variation of the two types of such agreements.

Both sides usually have been long known each other. A fit and proper test take place naturally, through everyday social intercourse. They already know each other the morality of its business partners. The owners know very well the people who do livestock, not just about its agreement alone but also those who believed it was known to have adequate knowledge and skills to cultivate the livestock.

This rustic-style wealth distribution mechanism practice is very pretty. On the one hand, livestock owners may not have enough time and skill to cultivate livestock, on the other hand herdsmen do not have the capital but have the time and skills to manage livestock. This cultivation that are developed in accordance with Islamic economics. Besides, we also know that sharing system which normally applies to the cultivation of rice. This fact proves that the farmer or rancher are already familiar with the revenue.

Seeing the reality of the above, it is fitting for us as academicians to pack for the culture of revenue (Gaduh and Paron) into the culture that led to the populist sharia economy. For this there needs, it is necessary to have the preservation of the culture by modeling and applying it in a sustainable manner and giving education about intensification and diversification with regard economic growing conditions.

From an economic perspective, cow-calf lease agreement and sharing system is the basis for a productive business community economic development in the region. It is of great potential for national food security, especially the needs of the flesh, given the support of the natural environment that still allows for the farm. The intensification and diversification, among others, can be done by making multifunctional cage, for the production of biogas from manure and the production of organic fertilizer from cow dung. The prolific pen systems, can be developed on any herdsmen who generally have side jobs in agriculture. Thus there are multiple outcomes that can be utilized by herdsmen (beef cattle workers) turns into biogas, which can be used for cooking and lighting home everyday.

Furthermore, from the dregs of the cow dung, can be used for the base material of organic fertilizer which can be used for sale to consumers or for the benefit of other agricultural enterprises, so as to increase agricultural production in addition to raising cattle.

Based on the explanation above, there are a variety of factors from the economic perspectives that effect the society to do revenue culture. These factors include: the benefits, in the village customs, beliefs, individual income, expenses, individual entrepreneurial spirit.

2. The implementation of Gaduh and Paron in terms of Cultural Perspective

The previous reseach of the implementation of revenue system in Srengat district Blitar result three paron system models; 1 . Landlord cooperates with tillers, overall cost is covered by the tenants and the results are 50\%: 50\%. The division of these findings are taken from the findings of net sales; 2 . Landlord cooperate with tillers, overall cost is covered by the owner and the results are $75 \%: 25 \%$ (owner: tenants/herdsmen). The division of these findings are taken from the findings of net sales. This model is called kedokan and it is now very rarely done; 
3. Landlord cooperates with tenants. Generally, the whole cost is covered by the tenant, but if owners want to provide fertilizer, then it is considered as a help which is not accounted in the end of period. The results are 50\%: 50\%. The division is taken from the findings of net sales.

While relating to rowdy system, there are several systems in Srengat district Blitar:

a. For the purpose of fattening cattle (beef)

Cattle owners purchase cattle and aim to be traded. After the cow was purchased then the cows are handed over at the cattle-keeping. Maintenance is carried out for 3-4 months. The entire feed and maintenance costs are paid by the farmer. Once the cow is ready for sale, then they are sold. The results of sales are divided by the amount of the distribution of the same portion of $50 \%$ : $50 \%$ which are taken based on the selling price.

b. Cows for the purpose of breed

The owner bought sires (male and female) to be maintained by the tenant/herdsmen. The entire feed and maintenance costs are paid by the farmer. There are two models in the revenue:

1) Type 1: if the cow gives birth, the first child is for the owner of the cow, while the second child is for the tenant/herdsmen and so forth.

2) Type 2: if the calves are sold, the revenue share is 50\%: 50\% of the selling. If the maintenance costs are paid by the owner, the proceeds is deducted in advance for the cost of consumables, and then it is divided by 50\%: $50 \%$.

The concept of culture is as a system of ideas, actions and man's work in the context of a society that is used by the human as self learning (Koentjaraningrat, 1990: 180) . Seeing from a cultural perspective, the sharing system of rice anvil / agricultural land and rowdy cow in Srengat districts Bitar has become a habit and culture of the community. Some cultural perspective that can be explored, namely:

First, a culture of mutual trust (honest) is very strongly reflected in the anvil system or farmland and rowdy cow. The culture of mutual trust can be seen from the pattern of the transaction / agreement / contract which is made orally (no written agreement).

Of key informant information, throughout the many years of experience contract is done only orally. Transaction is done for generations and has become habit. The culture of mutual trust which is still held strong in communities of farmers who implement the system for the revenur of the anvil and rowdy, until now is still maintained and followed. Cultural taboos denial of the appointment is still maintained within the farming community.

Second, a culture of mutual cooperation (mutual aid) and cooperation. As stated by key informants, most owners take the initiative to provide assistance in the form of fertilizer to the tenants outright, without taken into account in the final of revenue. So that they see it as pray. Similarly, when cattle ranchers suffer losses, some small owners provide assistance in the form of rupiah, although a small amount of rupiah but can be considered a form of participation losses, although the owner also has to bear the some losses. Beside that, at there are employers who sincerely provide capital to the cultivation of ducks to be managed independently.

Third, simple. Based on culture in a culture of mutual trust (honest) and mutual cooperation, culture raises sharing system (paron) and cow-calf lease agreement system (gaduh) which is implemented by community Srengat district in Blitar. The system is simple and practice. Data have been obtained from key 
informant show in sharing/revenue, a standard measure used is not stiff . Distribution of rice crops, such as rice or corn, land owners and tenants do not always use the size kilogram ( $\mathrm{kg}$ ), but they can use the container ( a ) of the bag or other container that can measure and calculate the appropriate harvest sharing agreement .

Based on the cultural perspective of rowdy and anvil system implemented in Sub Srengat Blitar, it has become a habit and a growing culture of mutual trust in the society. The culture of trust (strong hold honesty), a culture of mutual cooperation (mutual aid) and simple culture into a culture characterize the revenue system (cow-calf lease agreement and sharing system ).

\section{Implementation of Gaduh and Paron in terms of Islamic Perspective}

In the implementation of gaduh system and paron which is done in Srengat district in Blitar, the first model introduces a system of profit sharing by calculating the total cost of the maintenance. The concept is closer to justice because for all perpetrators of noise obtain benefit proportionately. The first model is presented in the following figure:

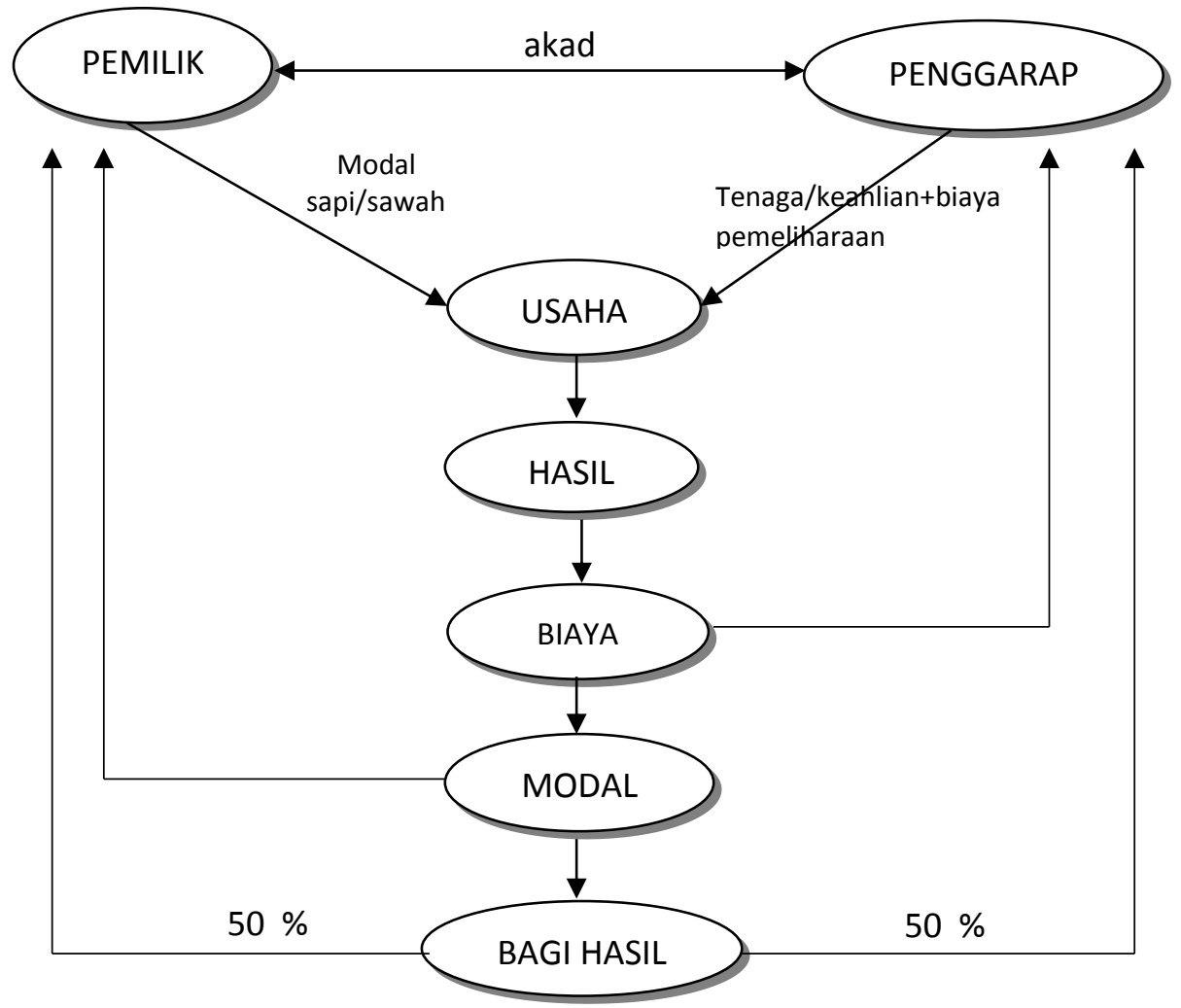

Figure 1 First Revenue Model

The second model is using a system of profit sharing but taking labor cost into account in the component of profit defisit. Therefore, the deduction for revenue which is based on the profit sharing is still in the proportion of 50:50. 


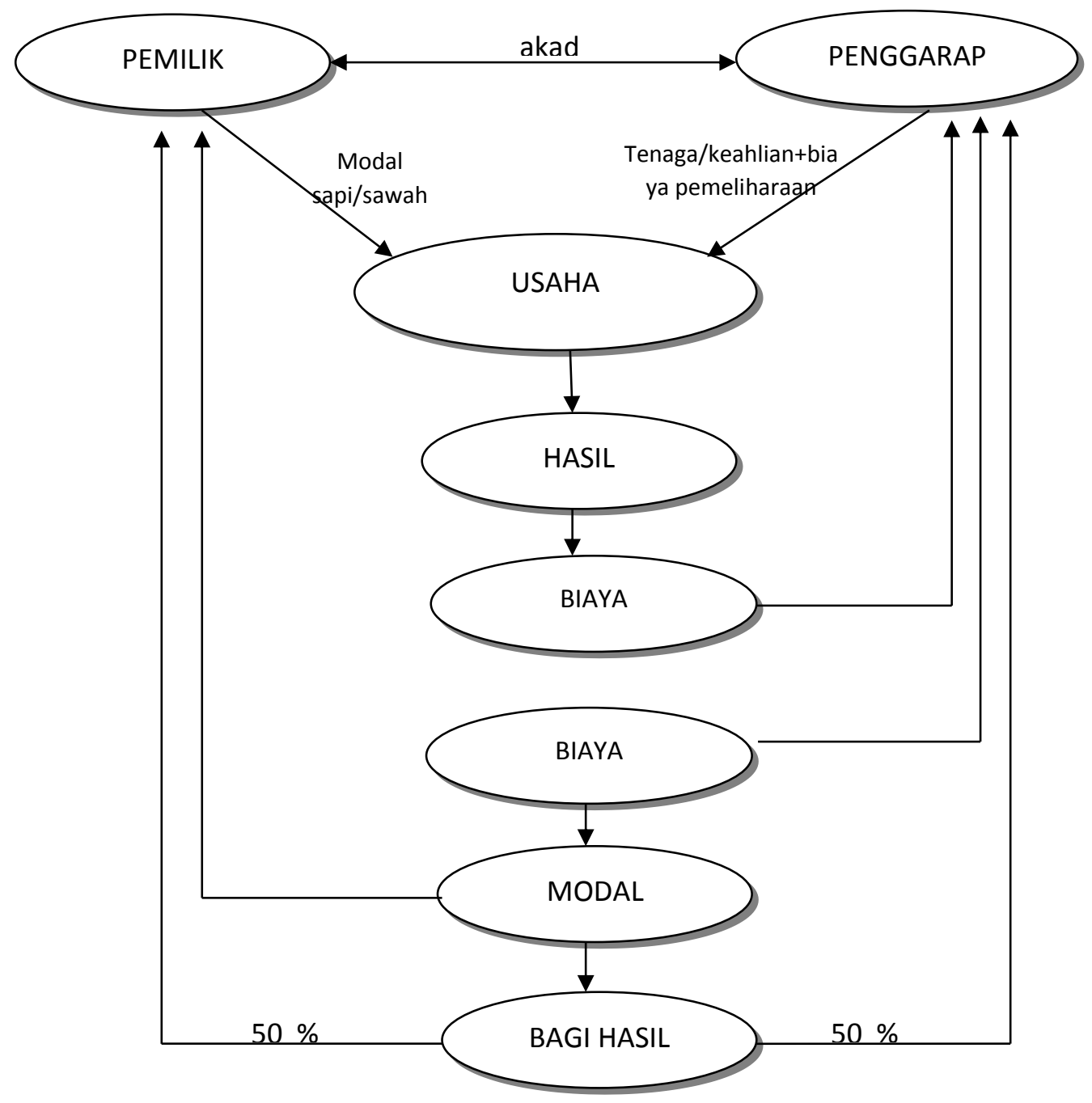

Figure 2 Second Revenue Model

While all third models uses the revenue sharing system without taking into account administrative costs and ranchers as a component of labor costs, but the proportion of profit sharing is 75: 25 . The proporsion is taken on the grounds of $25 \%$ to cover the costs of maintenance and labor. This proportion is also in accordance with the Decree of the Minister of the Interior and the Minister of Agriculture No. 211 of 1980 No. 714 / Kpts / um / 9/1980 on Guidelines for the Implementation of the Republic of Indonesia Presidential Decree No. 13 of 1980. These regulations are made to protect people who do not have knowledge about profit-sharing and closer to justice. For more details, a model for all three results are presented in the following figure: 


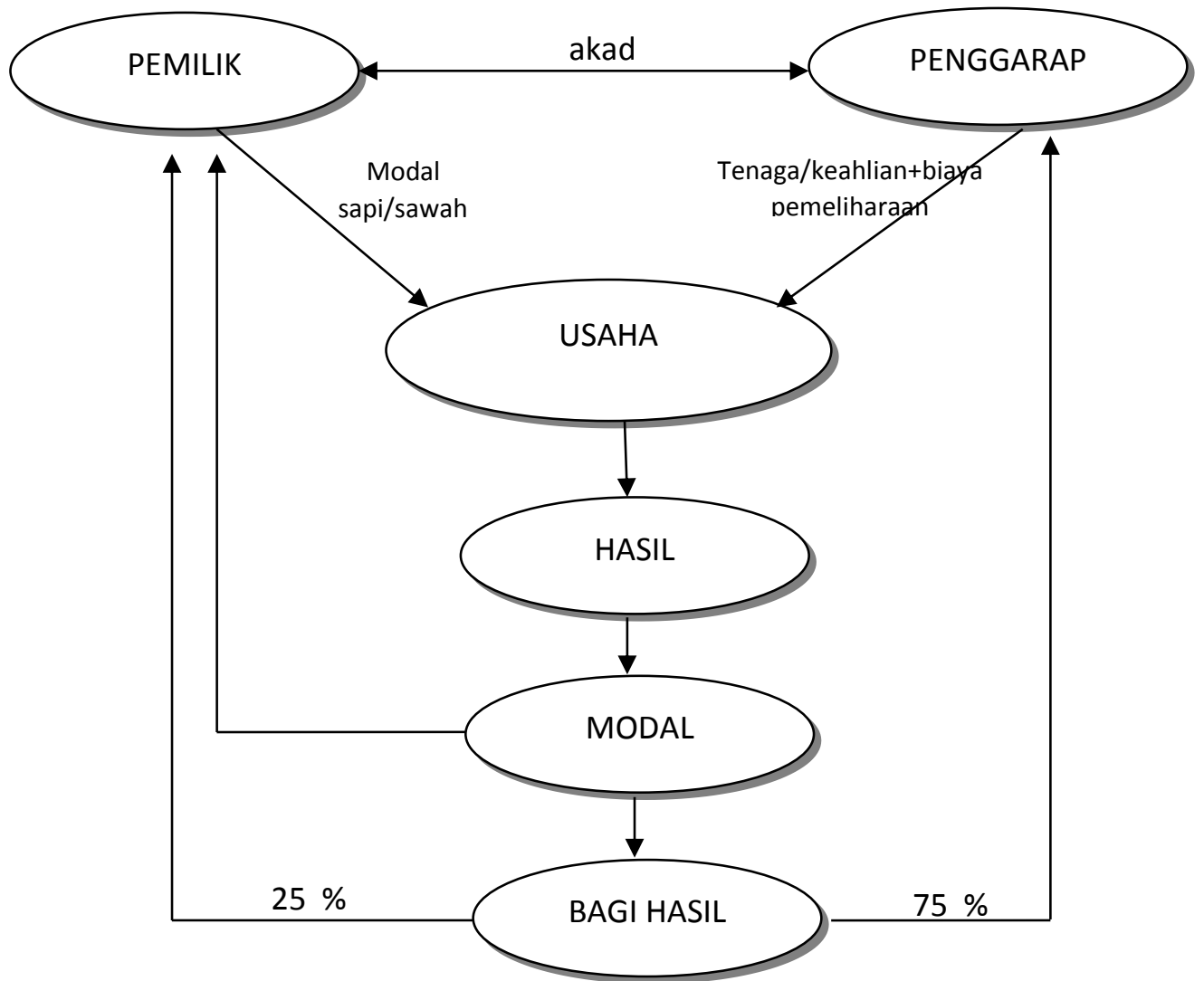

Figure 3 Third Revenue Model

Of the three models of implementation of revenue for rowdy and anvil system in the Srengat district Blitar, people use more on the third model (revenue sharing system) than in the two previous models. This is due to the fact that they do not want to be complicated by the certain calculations. Whereas they put forward the trust between each other.

The use of the profit sharing model and revenue sharing certainly has advantages and disanvantages. The advantage is that both of them are the best tool to remove the bank interest in a wide range of transactions and business practices and business. In addition, the levels of investment is higher because it is given the adequate supply of the capital which can be borrowed / distributed, because of the high and low results obtained by tenants are depending on their business. The more the result of the profit generated, the higher the benefits tenants. Thus, it is a motivation for them. This is a reflection of God's word in al-Qur'an Sura al-Najm 39-40: 


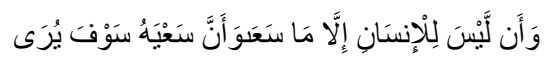

And that man no gain other than what has been earned. And that the venture will eventually be seen ( to him ).

While the weakness of the profit sharing and revenue sharing model need high flair and precision, because the Islamic economy is promoting honesty, while many businesses are less promoting it. Similarly, in shari'a banking practice, the significance of profit and loss sharing in the operational fund of bank investment is very weak. According to some Islamic banking observers, this happens for several reasons, including the reason of moral standards. There is a presumption that moral standards which are evolving in most muslim community do not give freedom of use of profit and loss sharing as an investment mechanism. It is based on the argument that encourage banks to hold more intensive monitoring of any such given investment. These things make banking operations uneconomic and inefficient. For this reason Islamic banks use finance profit and loss sharing that were granted after monitoring the depth of the business to be, the funds will only be granted to partners who manage the business efficiently, to be honest in the transaction, the running business projects is profitable, as well as business financing is generally in short term and not for long-term financing and not the financial institution.

Besides, there is also reason for the ineffectiveness of the model of profit and loss sharing financing. Financing profit and loss sharing do not serve a wide variety of financing needs of the ccontemporary economy. Nevertheless, profit and loss sharing which are applied in the form of mudharabah and musyarakah is the best tool to remove bank interest in a wide range of transactions and short term financing. In addition, this probably make institutional credit become overdue. Various problems related to the application of mudharabah and musyarakah at the level of institutional credit really can not be in use. The reason is that the increased demand for government debt to budgets, thus the request in the use of the loan by using a system of profit and loss sharing is not consummated.

Similarly, in providing funds for the system based on the results of profit and loss sharing requires higher vigilance on the part of banks in channeling their funds. Islamic banks are likely to improve the quality of their personnel by employing engineers and experts to evaluate the project management of the business to which they lend to look more carefully and be more observant than conventional bank lending technical. This will increase the costs incurred by bankers in maintaining the efficiency of banking performance that will directly impact on refund loans. This will lead to a greater burden on the users of these funds. Additional costs which are incurred by the bankers are used to maintain the operational effectiveness of Islamic banking. They will probably result in extra costs in half by a partner when returning the borrowed funds which are based on a system of profit sharing profit and loss sharing. (http://jejakimawan.wordpress.com/2012/05/30/profit-sharing-vs-revenuesharing/ downloaded on May 16, 2015).

In addition to using the model of revenue sharing system, the perpetrators of rowdy and anvil in Srengat district Blitar are also happy to use kedokan system, 
land or cattle owners provide capital in the form of rice or a cow to the tenants, as well as the costs for the maintenance outcome. While the revenue is conducted in the end of business after deducting for the maintenance cost. Due to the fact that tenants do not bear the maintenance costs, the profit sharing ratio which is received by tenants is smaller than the owner of the field / cow. More specifically, this kedokan system can be described as follows:

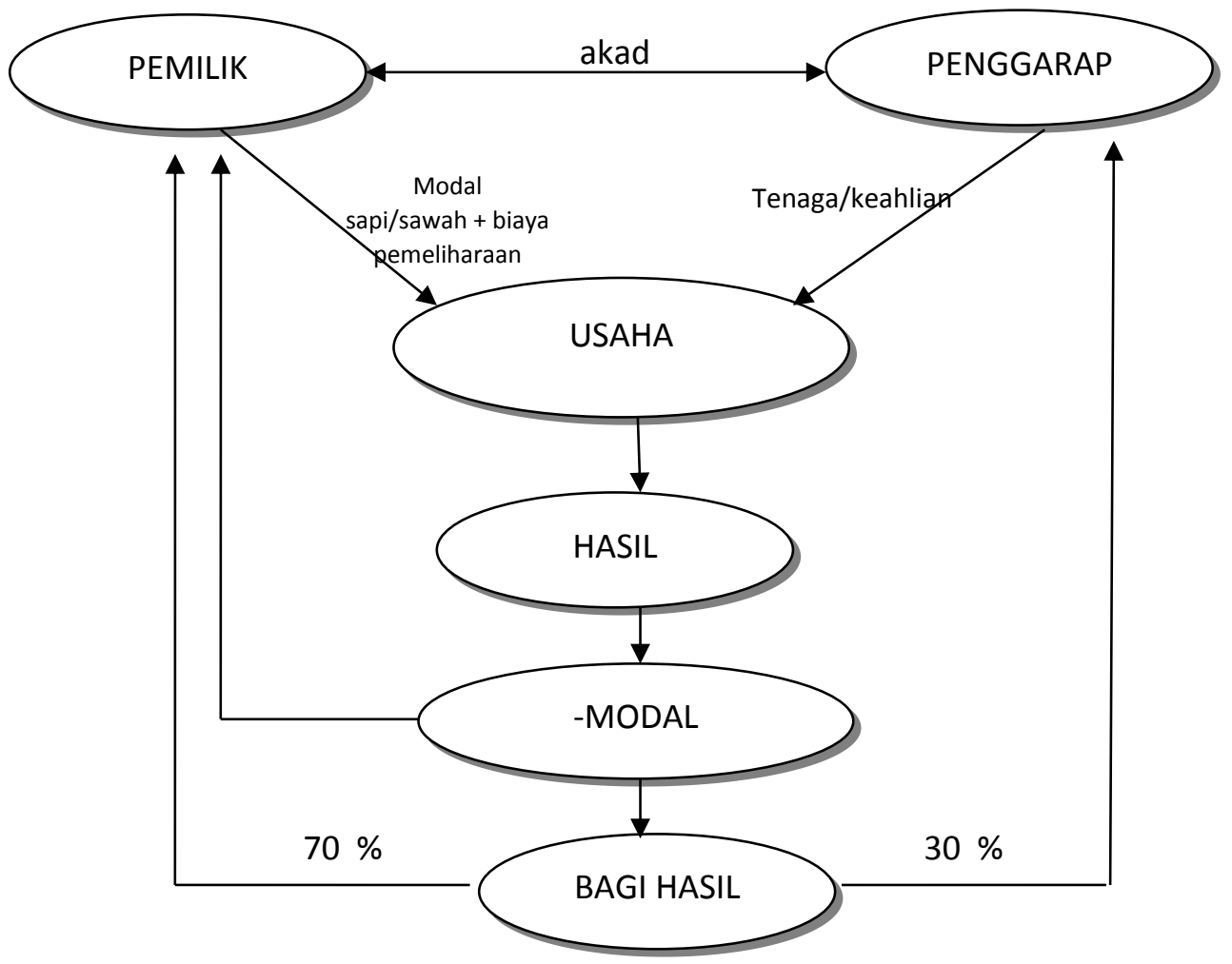

Figure 4 Kedokan System

In the kedokan system above, tenants are not burdened with the cost of seeds and the cost of maintenance. The one who provides seed and maintenance costs is land owners. So it could be said that the land owners employ the tenant but they are paid after finishing the work. The size of the reward depends on the yield. Those kinds of efforts in Islamic economics are like ujrah contract (wages hired), but because the wages given are from the things that are contracted and the vagueness of the amount of wages is given, then the system can not be categorized as ujrah contract. As described in Rozalinda (2005: 107) that terms of wages in the contract ujrah are (1) Wages form of objects which are known to be allowed to use it (the mall mutaqqwwim), (2) Something that is valuable or can be rewarded with money in accordance with local custom, (3) Wages / reward is not in the form of contracted things, for example, renting a house with a house.

In general, the residents of Srengat Blitar use three models of forms of cooperation in the field of agriculture explained above. In Shari'ah perspective, the 
models could be categorized as muzara'ah contract which is a form of cooperation between the owners of the land that gives the right to manage the land to the tiller with the results in accordance with the agreement as a condition. In muzara'ah, the landowner iss responsible for the cost of seed and maintenance. In addition, the kedokan system which is conducted by the residents of Srengat, Blitar can be categorized as a contract Mukhabarah, namely cooperation agricultural processing between landowners who provide land to the tiller with certain benefits (percentage) of crops in accordance with the agreement, and the seed comes of tenants.

While in the field of animal husbandry which is conducted by the residents of Srengat, Blitar in Shari'ah perspective could be categorized as Mudharabahc contract, the mutually beneficial cooperation between the capital owner with the manager (in this case the breeder). Capital will evolve so that farmers be helped in the work (to avoid unemployment), and the profits are divided by two. At a rowdy culture specifically for the purpose of fattening cattle, one drawback is never done recording by the cattle owner. While the maintenance costs, the result is determined based on the selling price. Therefore, it can be assured that the one who obtains the profit is financiers (the owner of the cow), while for farmers are not necessarily .In addition it has not fulfilled a 50:50 profit share based on profit sharing, but it is based on revenue sharing.

In Economics Shariah, the basis of trading attitude should remain a voluntary basis. It is listed in the Letter of Annisa; 29:

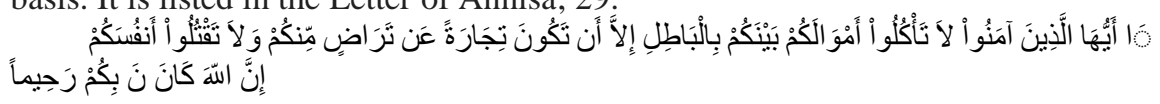

" O you who believe! Do not eat each other neighbor's property by way of vanity ( not true ), except in the trade applicable to consensual among you . And do not kill yourselves; Allah is Merciful to you ."

Thus, the main rule in trade is no coercion and on the basis of considerations which brings benefits, avoid madharat in social life, as well as maintaining the value of justice.

Specifically, the legal basis used in muzara'ah and Mukhabarah cooperation is a Hadith narrated by Ibn Umar "That Rasullullah gave the land of Khaibar to the Jews on the condition that they want to do and cultivate it and take some of the results". In addition, there is also a hadith narrated by Imam Bukhari "From Abdullah RA said: Rasullah has given the land to the Jews of Khaibar and he managed to get a share (reward) of what is produced from it."

In addition, there is also a hadith narrated by Imam Bukhari from Jabir who said that Arabs always cultivate their land by muzara'ah with the profit sharing ratio of 1/3: 2/3, 1/4:3/4, 1/2: 1/2, then Rasulullahpun said: "Let the planting or submit it to work on. Anyone who does not do one of them, resist the land".

While the sharing of muzara'ah and Mukhabarah, should be based on the overall results of paddy cultivation. It is appropriate with the hadith narrated by Imam Bukhari, Rafi 'bin Khadij Said: "Among The Ansar who most have the land are us, then the land is rented, most of the land for us and some of the land for those who do the work, sometimes it works well and the other is not successful, then therefore the Prophet Muhammad Prohibit paroan (sharing system )in that way. "This hadith explains that sharing paroan rice should not be based on any 
particular distribution of land, but the results of the overall management of the rice fields are in accordance with the previous agreement.

A leading scholar, Imam Ibn Qayyim, explains that the story of Khaibar is the dalils of muzara'ah and Mukhabarah which is done by dividing the results obtained between the owner and the workers, either in the form of fruits and other plants. Prophet himself was working with the people of Khaibar in this regard. Such cooperation may take place until late he died, and there is no proof that removing these laws. Even the caliph also do cooperation. Cooperation model is not included in this type of mu'ajarah (hiring people to work), but included in the Musharaka (partnership / collaboration), and is the same as for the results.

So also with the practice of mudaraba which is conducted by the residents of Srengat district Blitar is in conformity with the rules of Shari'ah. The legal basis is the hadeeth narrated by Ibn Majah from Suhaibah, he said: "There are three things that are endowed, namely the sale and purchase deferred, provide capital, and mix the wheat with dates for families, not for sale". Moreover, Imam Malik also told of A'la Bin Abdur Rahman bin Ya'qub of his grandfather, that he had been working on / managing assets Uthman ra, and the profits were divided by two.

In regard to the results of the residents of Srengat, Blitar use maro bati culture (for profit equally). In Islam, the division has been valid, because there has been a percentage value, mutually agreed and mutually benefited. Although when it is viewed from a quantitative scale, land owners and cattle owner get more benefit without considering the cost of care and labor. Thus, based on Islamic rules, the concept for this result is valid. However, closer to the values of justice, we need a model that creates mutual benefit economically and equally. In addition, in the long term, considering the cost of maintenance and labor will determine the level of productivity of rice crops and cattle.

Impact of Revenue Sharing Culture in Srengat district Blitar In Shariah Economic Perspective

The implementation of the results of muzara'ah system , mukhabarah and mudaraba in Srengat district Blitar has some impacts on the socio-economic growth sectors, such as :

1. Can create the mutual help or mutual need between the parties to cooperate by avoiding the practice of usury

2. Can add or increase income or economic sharecroppers and landowners to uphold justice .

3. Can reduce unemployment .

4. Can increase domestic agricultural production towards food self-sufficiency .

5. Can encourage the development of the real sector that sustains economic growth at the macro level .

6. Can optimize the unproductive land and turn them into productive and rewarding widely .

Results and Discussion with Quantitative Approach.

The quantitative approach this study uses PLS SEM analysis tool with the help of software WarpPLS 4.0. WarpPLS processing is the same as PLS and other evaluation measurements of outer and inner measurement evaluation. Inner measurement is to gauge whether or not the construct indicator is valid. While outer measurement is to measure the effect of exogenous variables on endogenous variables. Based on the measurement reliability and validity indicators show that all are valid and reliable as following indicators: 
Table 1 Model Fit and Quality Indices

Average path coefficient $(\mathrm{APC})=0.258, \mathrm{P}<0.001$

Average R-squared $(\mathrm{ARS})=0.476, \mathrm{P}=0.001$

Average adjusted R-squared (AARS) $=0.443, \mathrm{P}=0.004$

Average block VIF $(\mathrm{AVIF})=1.695$, acceptable if $<=5$, ideally $<=3.3$

Average full collinearity VIF (AFVIF) $=1.893$, acceptable if $<=5$, ideally $<=3.3$

Tenenhaus GoF $(\mathrm{GoF})=0.515$, small $>=0.1$, medium $>=0.25$, large $>=0.36$

Sympson's paradox ratio $(\mathrm{SPR})=1.000$, acceptable if $>=0.7$, ideally $=1$

R-squared contribution ratio $(\mathrm{RSCR})=1.000$, acceptable if $>=0.9$, ideally $=1$

Statistical suppression ratio $(\mathrm{SSR})=1.000$, acceptable if $>=0.7$

Nonlinear bivariate causality direction ratio $(\mathrm{NLBCDR})=1.000$, acceptable if $>=$ 0.7

Based on Table 1 it appears that:

1. The value of $\mathrm{P}$ values for APC, ARS, and Aars $<0.001$ with $\mathrm{APC}=0258$, the value of ARS $=0476$ and the value of Aars $=0443$.

2. Value of AVIF and AFVIF generated $<=3.3$ which means that no multicoloniarity matter between indicators and between exogenous variables.

3. GoF generated 0515> 0:36 which means a very good fit model.

4. SPR, RSCR, SSR, and NLBCDR generate value $=1$ so there is no problem of causality in the model.

To the effect of exogenous variables on endogenous variables which is shown in Table 4.2 shows that economic perspectives affect the community empowerment. This is demonstrated by $p$-value $<0.05$. Similarly cultural and social perspective also affect the community empowerment. While the Sharia perspective has no effect on the community empowerment. It is due to the fact that p-value indicates $>0.05$.

The magnitude of effect sizes of economic perspective and the perspective of the cultural and social empowerment of the people is secondary because it shows $>0: 15$ while the effect sizes of Sharia perspective on community empowerment figures show $>0.02$ which means small influence.

Table 2 Effect Sizes

\begin{tabular}{|c|c|c|c|}
\hline \multicolumn{4}{|c|}{ Path coefficients } \\
\hline \multicolumn{4}{|c|}{$\begin{array}{lll}\text { EKO SYR } & \text { BDY }\end{array}$} \\
\hline \multicolumn{4}{|c|}{ EKO } \\
\hline \multicolumn{4}{|l|}{ SYR } \\
\hline \multicolumn{4}{|l|}{ BDY } \\
\hline PDM & 0.469 & 0.018 & 0.288 \\
\hline \multicolumn{4}{|c|}{$P$ values } \\
\hline$\overline{\mathrm{EKO}}$ & SYR & BDY & PDM \\
\hline \multicolumn{4}{|l|}{ EKO } \\
\hline \multicolumn{4}{|l|}{ SYR } \\
\hline \multicolumn{4}{|l|}{ BDY } \\
\hline PDM & 0.011 & 0.454 & 0.012 \\
\hline
\end{tabular}




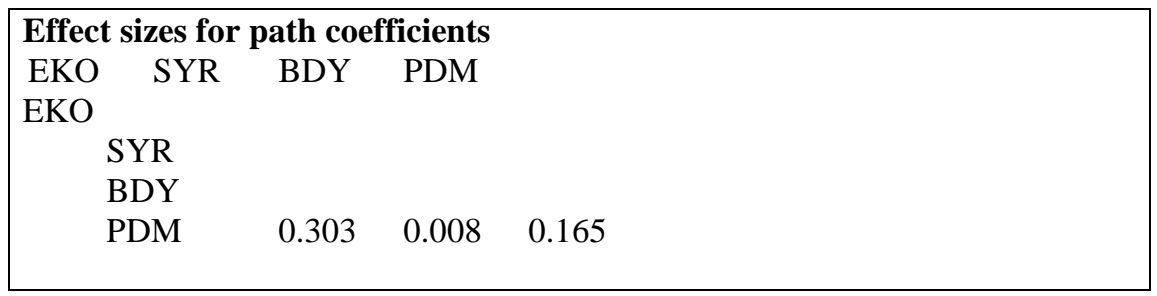

Table 3 shows whether or not the indicators forming the construct valid and reliable. It is said to be valid if the indicator has a value of loading factor $<=0.6$. This is because research is still to be explanatory. So that all the indicators that have a value $<0.6$ to be at the drop of this research model. As in the picture 4.3. shows that :

1. There are four sub-indicators which are valid and reliable in indicators of forming the construct / variable economic perspective , they are ; increasing welfare ( X2 ), reduced unemployment ( X3 ), increased revenue ( X9) , as well as increased welfare (X12)

2. Likewise there are five indicators related to the indicator forming constructs / variables sharia perspective which are valid and reliable. The indicator is Worship ( X13), no deception ( X21), agreement ( X22), unfair advantage ( x23), and no one harmed ( X24) .

3. Variable cultural and social perspectives have indicators of which are valid and reliable.

4. While the indicator forming an exogenous variable that is empowering the community has four indicators that have a value higher loading factor, among others: increased income (Y1), community togetherness (Y2), the maximum in work (Y4), and feel safe and comfortable because it was within the rules and religion (Y5).

Table 3 Combined Loadings and Cross-Loadings

\begin{tabular}{|llllllll|}
\hline EKO & SYR & BDY & PDM & Type (a SE & P value & \\
X3 & 0.723 & -0.038 & 0.089 & 0.088 & Reflect & 0.192 & $<0.001$ \\
X9 & 0.789 & 0.065 & 0.076 & 0.110 & Reflect & 0.192 & $<0.001$ \\
X12 & 0.732 & -0.084 & -0.021 & -0.310 & Reflect & 0.142 & $<0.001$ \\
X2 & 0.783 & 0.048 & -0.138 & 0.097 & Reflect & 0.154 & $<0.001$ \\
X13 & -0.396 & 0.640 & 0.013 & 0.139 & Reflect & 0.173 & $<0.001$ \\
X21 & 0.331 & 0.731 & 0.336 & -0.581 & Reflect & 0.235 & 0.002 \\
X22 & -0.099 & 0.765 & -0.317 & 0.286 & Reflect & 0.131 & $<0.001$ \\
X23 & 0.021 & 0.850 & -0.150 & 0.234 & Reflect & 0.101 & $<0.001$ \\
X24 & 0.099 & 0.700 & 0.165 & -0.118 & Reflect & 0.298 & 0.011 \\
X25 & -0.649 & 0.118 & 0.680 & 0.161 & Reflect & 0.163 & $<0.001$ \\
X26 & -0.090 & 0.222 & 0.664 & -0.036 & Reflect & 0.178 & $<0.001$ \\
X27 & -0.082 & 0.179 & 0.794 & -0.014 & Reflect & 0.132 & $<0.001$ \\
X28 & -0.369 & 0.040 & 0.623 & 0.504 & Reflect & 0.178 & $<0.001$ \\
X29 & 0.559 & -0.093 & 0.734 & -0.358 & Reflect & 0.200 & $<0.001$ \\
X30 & 0.190 & -0.081 & 0.768 & -0.150 & Reflect & 0.123 & $<0.001$ \\
X31 & 0.046 & -0.327 & 0.656 & 0.253 & Reflect & 0.173 & $<0.001$ \\
X32 & 0.278 & 0.148 & 0.724 & -0.288 & Reflect & 0.164 & $<0.001$ \\
\hline
\end{tabular}




\begin{tabular}{|llllllll|}
\hline X33 & 0.014 & -0.231 & 0.681 & 0.047 & Reflect & 0.244 & 0.004 \\
Y1 & 0.024 & -0.024 & -0.054 & 0.828 & Reflect & 0.109 & $<0.001$ \\
Y2 & -0.142 & 0.126 & 0.158 & 0.791 & Reflect & 0.145 & $<0.001$ \\
Y4 & 0.078 & -0.010 & -0.220 & 0.788 & Reflect & 0.145 & $<0.001$ \\
Y5 & 0.043 & -0.100 & 0.130 & 0.717 & Reflect & 0.159 & $<0.001$ \\
Notes: Loadings are unrotated and cross-loadings are oblique-rotated. SEs and P \\
values are for loadings. P values $<0.05$ are desirable for reflective indicators. \\
\hline
\end{tabular}

Table 4 shows that the value of $\mathrm{R}$-squre model of this study was 0,476 , or $47.6 \%$, means that the empowerment of communities affected by the economic perspective, sharia perspective and the perspective of cultural and social activities. The remaining $52.4 \%$ is influenced by other variables outside the model of this study.

Composite reliability values of all variables showed a number $>0.7$, which means very good so it fills internal consistency reliability. VIFs collinearity full value indicates the number $<3.3$ so means there is no problem in collinearity. AVE values are average figures as it is shown 0.5 corresponding to type of explanatory or confirmatory study.

Table 4 Latent Variable Coefficients

\section{R-squared coefficients \\ EKOSYRBDYPDM 0.476 \\ Adjusted R-squared coefficients \\ EKOSYRBDYPDM 0.443 \\ Composite reliability coefficients \\ EKOSYRBDYPDM}

0.8430 .8570 .8980 .863

Cronbach's alpha coefficients

EKOSYRBDYPDM

0.7510 .7910 .8720 .787

Average variances extracted

EKOSYRBDYPDM

0.5730 .5480 .4970 .612

Full collinearity VIFs

2.0641.6441.9561.907

Q-squared coefficients

EKOSYRBDYPDM

From Figure 6 it can be seen that the economic perspective has a great influence on the cultural output of rowdy / anvil fields. Economic perspective in terms of the main livelihood indicators, improve people's welfare, reduce the unemployment rate is a pleasant business, having job side, becoming financiers, improving the welfare of the family.

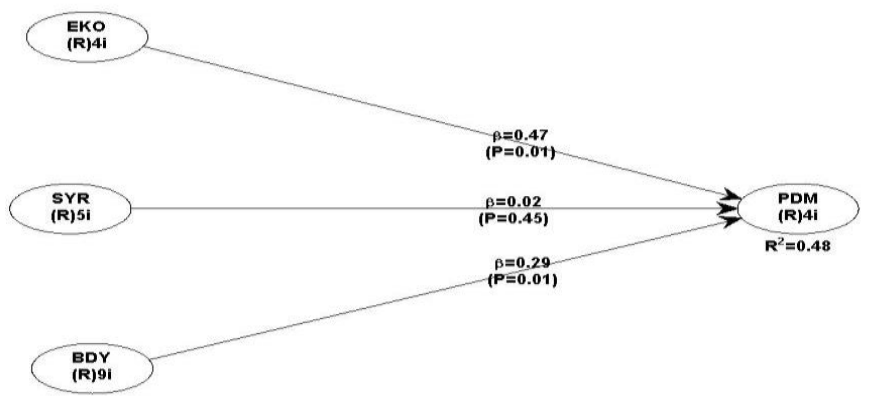

Figure 6 


\section{CONCLUSION}

From the qualitative analysis shows that there are some cow-calf lease agreements (gaduh) and share farming (paron) system in Srengat: 1). For the purpose of fattening cattle (beef cattle). Results of sales are divided by the amount of the distribution of the same portion of 50\%: 50\% which are taken based on the selling price; 2). Cows bred for the purpose. There are two models in the distribution of the resvenue: Type 1: The first calves become the property of the owner, while the second is a right of calf cattle belonging. Type 2: If the feed and maintenance costs are paid by the owner, the proceeds are deducted in advance for the cost of consumables, and then divided by 50\%: 50\%. While the anvil fields, the revenue uses a system of profit sharing, revenue sharing and kedokan. In general, the system noise and anvil rice practiced by rural communities are in accordance with the Islamic Shari'ah.

There are three perspectives in the system of rowdy cow / anvil rice namely the economic perspective, sharia perspective and the perspective of cultural and social. Of quantitative analysis shows that the economic perspectives have a greater influence than others. The economic perspectives include increased welfare, reduce unemployment, increase income, as well as increased prosperity which has the greatest impact.

\section{Suggestion}

1. In the share farming system needs an integrated system between the Department of Agriculture and citizens to establish a mechanism in terms of capital, knowledge , maintenance management , and mastery of technology .

2. For the development model of cow-calf lease agreement is expected to avoid a system that not only top-down but also must be bottom up .

\section{References}

Abdurrahman, H. (2005). Mauqif al-shari'ah al-Islamiyah min al-Bunuk. Kairo: Dar al-Salam.

Antara. (2011). http://www.antarakaltim.com/print/10583/program-pengadaanbibit-sapi-berau-tidak-gagal. Diunduh 22 April 2013.

Atmojo, A. S. (2012). Perjanjian Bagi Hasil Ternak Sapi Antara Peternak dengan Dinas Peternakan Kabupaten Kulonprogo. Yogyakarta: Universitas Islam Indonesia.

Berita Resmi Statistik No. 75/11/Th. XV, 5 November 2012.

Bintarto, R. (1980). Gotong-Royong : Suatu Karakteristik Bangsa Indonesia. Surabaya : PT. Bina Ilmu.

Burnita, M. (2010). Sistem Bagi Hasil dan Pola Hubungan Sosial Antara Petani Pemilik Dengan Petani Penggarap di Pedesaan Sumatera Barat (Studi Kasus 
Economic Perspective, Cultural Perspectives, and Sharia Perspective in Revenue Sharing For Village Economic Empowerment (Case Study on Gaduh Culture in East Java)

pada Masyarakat Kenagarian Limo Koto, Kecamatan Bonjol, Kabupaten Pasaman). Padang; Universitas Andalas.

Chapra, M.U. (2001). The Future of Economics: An Islamic Perspective. Jakarta: Shari,ah Economics and Banking Institute (SEBI).

Haneef, M. A. (2006). Pemikiran Ekonomi Islam Kontemporer. Surabaya: Airlangga University Press.

Hosen, M. N., Ali, H., \& Muhtasib, B. (2008). Ekonomi Syariah. Jakarta: Pusat Komunikasi Ekonomi Syariah (PKES).

Iko, H. (2008). Pelaksanaan Perjanjian Bagi Hasil Tanah Pertanian di Kecamatan Bulakamba Kabupaten Brebes Jawa Tengah. Semarang: Pascasarjana Universitas Diponegoro.

Isnawati, L. (2008). Pemanfaatan Gadai Sawah di Dukuh Brunggang Sangen, Desa Krajan, Kecamatan Weru, Kabupaten Sukoharjo (Sebuah Kajian Normatif dan Sosiologi Hukum Islam). Yogyakarta: Universitas Negeri Sunan Kalijaga.

Kayam, U. Prisma No.3 Th XVI 1987. Keselarasan dan Kebersamaan : Suatu Penjelajahan Awal. Jakarta: LP3ES.

Khairudin, M. (2009). Praktik Bagi Hasil Nggado Sapi di Desa Grantung Kecamata Bayan Kabupaten Purworejo Menurut Hukum Islam. Yogyakarta: Universitas Islam Negeri Sunan Kalijaga.

Khan, A. (2008). Kapitalisme di Ujung Tanduk. Jakarta: Pustaka Tharikul Izzah.

Koentjaraningrat. (1983). Ciri-Ciri Kehidupan Masyarakat Pedesaan di Indonesia. dalam Sajogyo dan Sajogyo, Pudjiwati. Sosiologi Pedesaan. Jilid 1. Yogyakarta: Gadjah Mada University Press.

Koentjaraningrat. (1990). Pengantar Ilmu Antropologi. Jakarta: Rineka Cipta LG035/red.003. 2013. Ternak Bagi Hasil Peternakan Ketapang Mulai Jadi Sumber PAD. http://www.lintasgayo.com/34868/ternak-bagi-hasilpeternakan-ketapang-mulai-jadi-sumber-pad.html. Diunduh 22 April 2013.

Lubis, S. K. (2000). Hukum Ekonomi Islam. Jakarta: Sinar Grafika

Mardani. (2012). Fiqh Ekonomi Syari'ah. Jakarta: Kencana.

Edwin, M., dkk. (2006). Pengenalan Eksklusif Ekonomi Islam. Jakarta: Kencana.

Efendi, N. M. (2002). Islam and Business. Malaysia: Pelanduk Publications. 
Parsons, T. (1951). The Social System. New York : Amerind Publishing Co. Pvt. Ltd.

Syafi’i, R. (2004). Fiqih Muamalah. Bandung: Pustaka Setia.

Rencana Pembangunan Jangka Menengah Daerah (RPJMD) Kabupaten Blitar 2011-2016.

Rozalinda. (2005). Fiqh Muamalah dan Aplikasinya Pada Perbankan Syariah. Padang: Hayfa Press.

Saepudin, E. (2012). http://www.aktual.co/ekonomi/123745swasembada-sapi2014-dipastikan-gagal-total-. Diunduh 22 April 2013.

Sajogyo., \& Sajogyo, P. (1992). Sosiologi Pedesaan (Jilid 1 dan 2). Yogyakarta : Gadjah Mada University Press.

Sakti, A. (2007). Analisis Teoritis Ekonomi Islam. Paradigma dan aqsa opublishing.

Saputra, D. (2009). Pelaksanaan Perjanjian Bagi Hasil Sawah di Kecamatan Kamang Magek Kabupaten Agam. Padang: Universitas Andalas.

Syafi'i, R. (2004). Fiqih Muamalah. Bandung: Pustaka Setia.

T.pso-099/R007 . 2010. http://makassar.antaranews.com/berita/17285/programsejuta-sapi-sulsel-terancam-gagal. Diunduh 22 April 2013.

Tan, I. (2009) .Bisnis dan Investasi Sistem Syari'ah. Yogyakarta: Universitas Atma Jaya.

Tashadi, M., Gatot, S., \& Sukirman. (1982). Sistem Gotong Royong dalam Masyarakat Pedesaan Daerah Istimewa Yogyakarta. Jakarta: Departemen Pendidikan dan Kebudayaan.

Wahyu. (2012). http://fakfakinfo.com/2012/01/karena$\% \mathrm{E} 2 \% 80 \% 9 \mathrm{Csbg} \% \mathrm{E} 2 \% 80 \% 9 \mathrm{D}$-program-sapi-bomberay-terancam-gagal/ Diunduh 22 April 2013.

Web site resmi kabupaten blitar. http://www.blitarkab.go.id/?p=272. Diunduh 22 April 2013. 